\title{
THE DEPENDABILITY EVALUATION OF RAILBUSES OCENA NIEZAWODNOŚCI AUTOBUSÓW SZYNOWYCH
}

\author{
Izabela Dziaduch \\ Politechnika Wroclawska, Wydział Mechniczny \\ e-mail: izabela.dziaduch@pwr.wroc.pl
}

\begin{abstract}
In the paper, the results of dependability evaluation of railbuses are presented. These results are the basis for assessment of their durability. Selected indicators and characteristics are used to evaluate the dependability of railbuses. Information about the operation and maintenance has been obtained from the railway company, which performs the passenger transport with the use of railbuses. The research analysis contains 8 single mode railbuses of type $X$ (manufactured by the same producer).
\end{abstract}

Keywords: dependability, railbus, passenger rail transport

Streszczenie: $W$ artykule przedstawiono wyniki oceny niezawodności autobusów szynowych, które stanowia podstawe oceny ich trwatości. Oceny dokonano na podstawie wybranych wskaźników i charakterystyk, do obliczenia których wykorzystano dane z przebiegu eksploatacji 8 jednoczlonowych autobusów szynowych wykonanych przez firme $X$ użytkowanych $i$ obslugiwanych przez jedno z regionalnych przedsiębiorstw kolejowych.

Słowa kluczowe: niezawodność, autobus szynowy, pasażerski transport kolejowy 
The dependability evaluation of railbuses

Ocena niezawodności autobusów szynowych

\section{Introduction}

The exploitation process is defined as alternating changes of technical object' exploitation states, which are determined by its operation and maintenance conditions and relevant activities. The term of a technical object, used in the paper, corresponds to railbus. Every object goes through operation and maintenance phases in its entire useful life. It is assumed that, the object is operated when it is in availability state and is maintenanced if it is in unavailability state. Knowledge of the time distribution in these states allows to develop characteristics of dependability evaluation of technical object [2].

The aim of this paper is to present the results of the analysis of the operation and maintenance processes of single mode railbuses of type $X$ (manufactured by the same producer). The scope of research was limited to the object's dependability evaluation.

The paper consists of five sections. After Introduction, i.e. in the section 2, the research objects are shortly discussed. A research description is presented in the next section. Later in section 4, numerical and functional characteristics of dependability, which used to evaluation of railbuses dependability, are shown. A brief summary and conclusions are included in the final section.

\section{Railbus as research object}

The railbus is a lightweight rail vehicle that is designed to carry passengers specifically on little-used railway lines. It is propelled by a diesel engine mounted underneath the floor of the coach. A characteristic feature of railuses is low floor, which enables easy access for bicycles, strollers, suitcases, wheelchairs etc. The term railbus is usually used with reference to a train consisting of a single coach, with a driver's cab at both ends. The general scheme presenting the construction of single mode railbuses of type $\mathrm{X}$ is shown in Figure 1 .

\section{Cab B}

Cab A

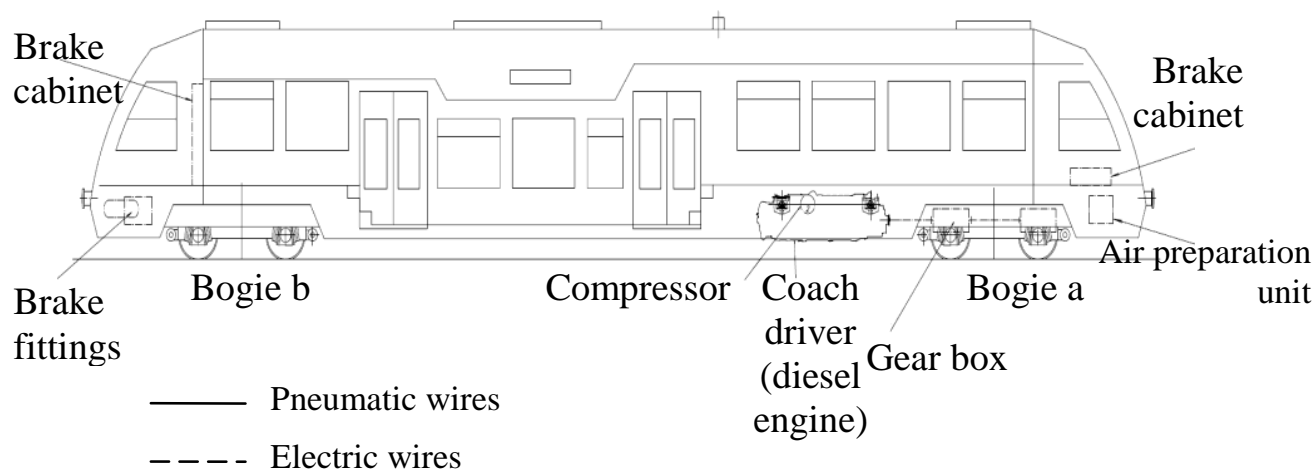

Fig. 1. The general scheme of construction of single mode railbuses of type X [1] 
The functional structure of a railbus includes [1]:

- assemblies - sub-assemblies forming functionally one whole, for example bogie,

- sub-assemblies - groups of elements forming one constructional entirety, for example wheelset,

- elements - indivisible parts of assembly and sub-assembly such as wheelset axle that can be combined into systems for example running system.

The railbus consists of repairable and non- repairable elements. As a whole, these vehicles belong to a group of repaired objects with finite time of recovery. Restoration is done by replacing the damaged element with a new one or its repair.

\section{Description of research}

Dependability information has been obtained from the railway company, which performs the passenger transport process with the use of railbuses. The analyzed rail carrier has begun transport activities on the $14^{\text {th }}$ December 2008 , and now operates twelve railway lines. The rail carrier possesses twenty - one railbuses (eleven binary railbuses and ten single mode railbuses) that have been bought by Province Marshall Office. All vehicles are operated by the analysed rail carrier, alternately on the same routes, and in similar conditions.

The research analysis contains eight single mode railbuses of type $X$ (manufactured by the same producer). All analysed vehicles are homogeneous collection of objects in terms of design solutions. Among the objects of research are five new railbuses and three ones previously operated by another rail carrier. The vehicles were in possession of analysed company in different instants of time, as illustrated in Figure 2.



Fig. 2. The analysis time period 
The dependability evaluation of railbuses

Ocena niezawodności autobusów szynowych

Mileage of railbuses, from the moment of entry into operation to the moment of the end of the study, is presented in Figure 3.

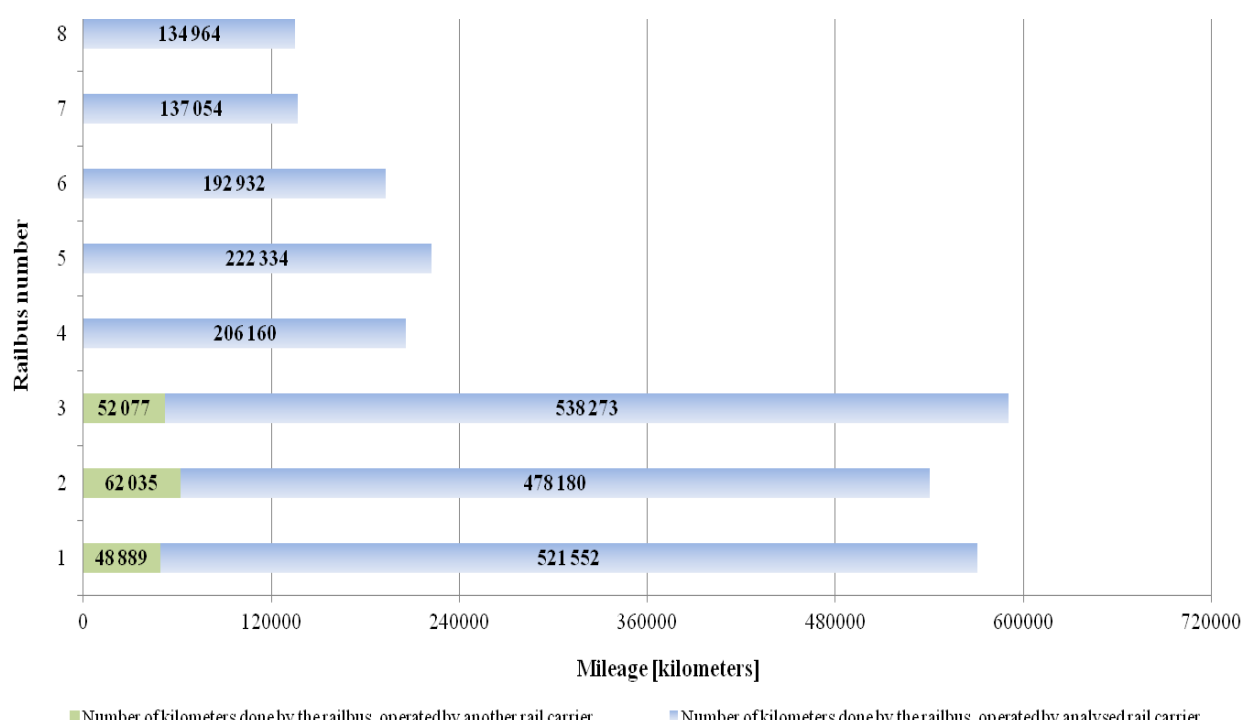

Fig. 3. Railbuses operation time expressed in mileage

The period of analysis covers 1295 calendar days, from the $14^{\text {th }}$ December 2008 to $30^{\text {th }}$ June 2012.

The data about rail buses' operation and maintenance process performance are taken from service reports and their board books which are prepared by technical department's employees. The board books are located in every railbus, and are filled in by engine drivers, warehousemen and service engineers, while the service reports are filled in only by service engineers. These documents contain information on:

- fuel level available in the petrol tank according to the on board computer indication,

- the (moment) date of failure and its removal (maintenance),

- all failures and irregularities detected during operational process performance

- the (moment) date of the start and end planned maintenance,

- type of performed planned maintenance,

- mileage and hours of engine work registered at the moment of maintenance,

- exploitation materials and spare parts used during the maintenance actions.

Operation and maintenance history of the analyzed vehicles is not complete. Entries in the books and the reports are missing. Moreover, in any of these documents, there is no clear information about the repair time. Therefore, 
information obtained during interviews with service personnel and technical department was taken into account in dependability analysis of railbuses.

In the analysed period, 598 corrective maintenances (current repairs) were observed. Among them there were 9 maintenances $(1.5 \%)$ without the ability to identify repaired parts. Corrective maintenances were often performed during preventive ones (Figure 4).



Fig. 4. The percentage of the number of repairs performed during planned and unplanned maintenances

Within these 589 current repairs, the service personnel performed 864 maintenance actions. The railbuses appeared with varying frequency in the records of report, as shown in Figure 5.

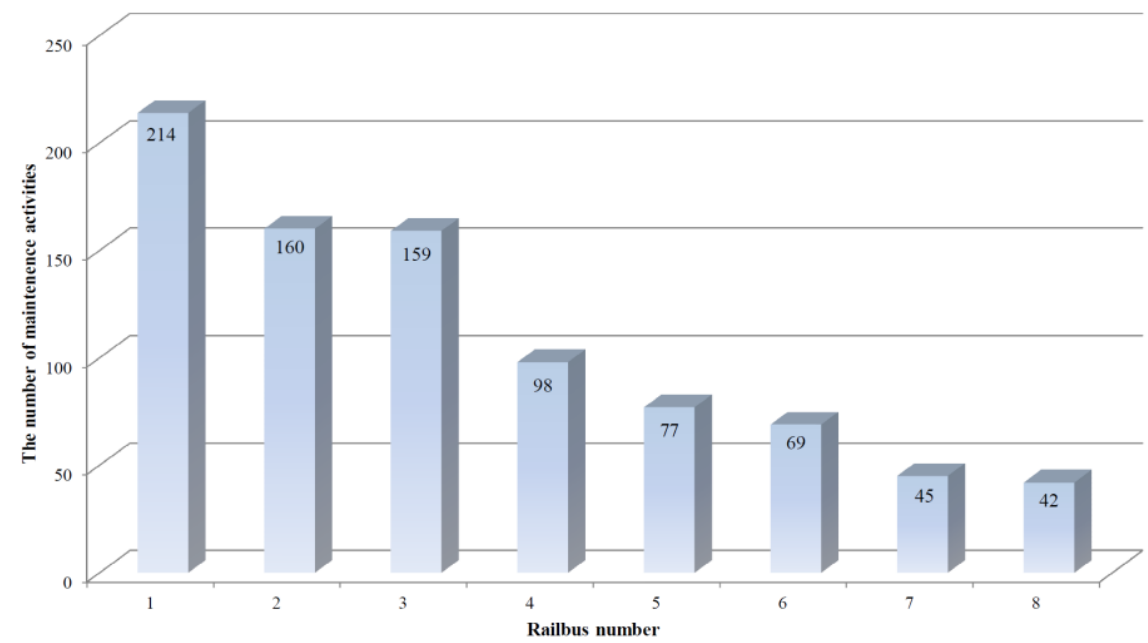

Fig. 5. The number of maintenance actions performed in each analyzed railbus

During the analyzed time period, $44 \%$ corrective maintenance actions were done by replacing the damaged element with a new one, and $56 \%$ by its repair. 
Failure is analysed at the level of complexity of the vehicle. Vehicle failure, as a result, is caused by failures of its elements. To easily systematize all elements included in the railbus, the following functional systems of railbus are assumed:

- body system,

- running system,

- driver line system,

- braking and pneumatic system,

- electric system,

- climatic system,

- communication and control system,

- external devices.

The failures of elements of railbus, which were recorded during the research, were divided into four groups [3]:

- critical failure - failure, which causes stop of vehicle usage,

- important failure - failure, which requires immediate action to restore the object,

- unimportant failure - failure, in which performing of the action required to restore the object can be postponed in time,

- irrelevant failure - failure, which influence on operating of object can be omitted.

The dependability analysis of railuses including:

- construction of histograms and cumulative distribution function of availability times and repair times,

- verification of the hypothesis about the form of distributions of availability times and repair times

- estimation of unknown parameters of distributions,

were carried out using Weibull++ software.

\section{Research results}

At first, the availability rate, calculated from the formula (1) is analyzed (Figure 6).

$$
A=\frac{T_{Z}}{T_{Z}+T_{N Z}}
$$

where:

$A$ - availability of railbus,

$T_{Z}$ - total time of availability (operating),

$T_{N Z}$ - total time of unavailability (maintenance).

In the calculations, the total time of unavailability is assumed as the sum of time of unavailability caused by both corrective and preventive maintenance. Moreover, time of unavailability is the sum of the times: repair and waiting for maintenance. All times are expressed in hours. 


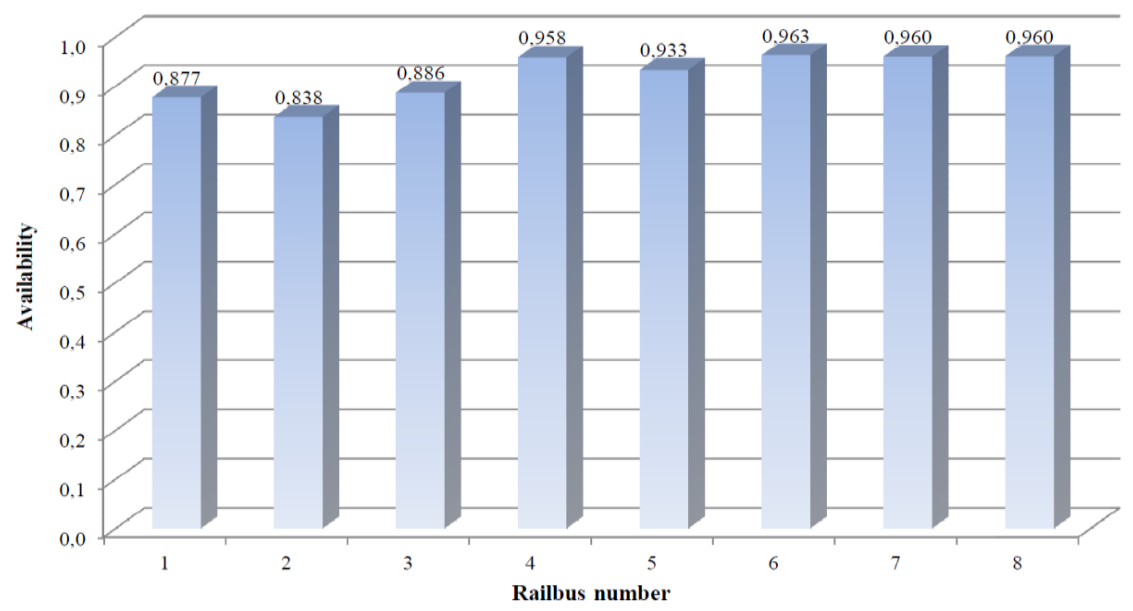

Fig. 6. Availability rate for analyzed railbuses

As it can be seen at the Figure 6, the average availability ratio is equal 0.9. During the analyzed time period, railbuses with numbers $1 \div 3$ had lower availability rates than others. This can be connected with longer operational time of this railbus (in use till 2008) and more data gathered during the research analysis.

Next, the maintainability rate, calculated from the formula (2), is determined (Figure 7).

$$
M=\frac{T_{N Z}}{T_{Z}+T_{N Z}}(2)
$$

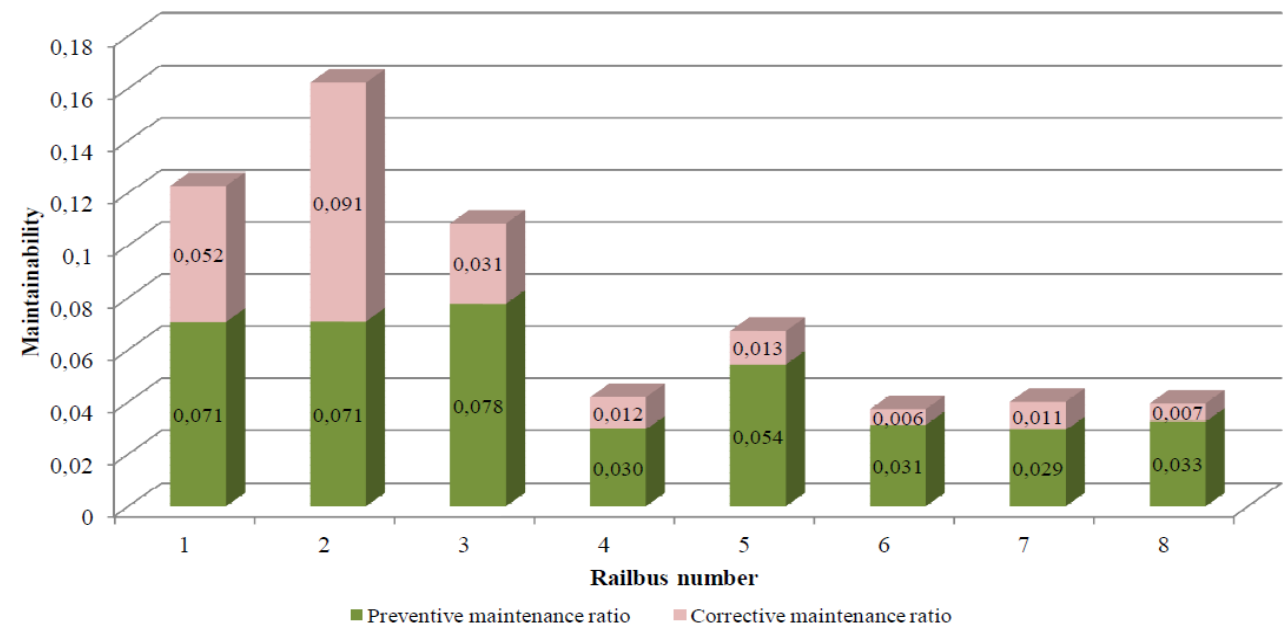

Fig. 7. Corrective and preventive maintainability rate for analyzed railbuses

The average maintainability rate is equal to 0.1 . The average preventive maintainability rate is the higher than the average corrective maintainability rate. 
The dependability evaluation of railbuses

Ocena niezawodności autobusów szynowych

These rates are respectively 0.6 and 0.4 . Railbuses with numbers $4 \div 8$ are in use by shorter period of time than railbuses with numbers $1 \div 3$, therefore, they have a small maintenance rates. As it can be seen at the Figure 7, the corrective maintainability rates are much lower for vehicles $4 \div 8$ that $1 \div 3$. It can be related to shorter operational time of these railbuses. The average value of the corrective maintainability ratio oscillates at a relatively low level, given the fact that the current rail buses are in the so-called Early Failure Period (also referred to as Infant Mortality Period), when the failure rate is high and gradually decreases - in order to stabilize during useful life (mean age of single mode railbuses, which are the object of this study, is approximately 2.5 years).

Based on the information about the damaged elements, the analysis of functional systems of railbuses were carried out (Figure 8).

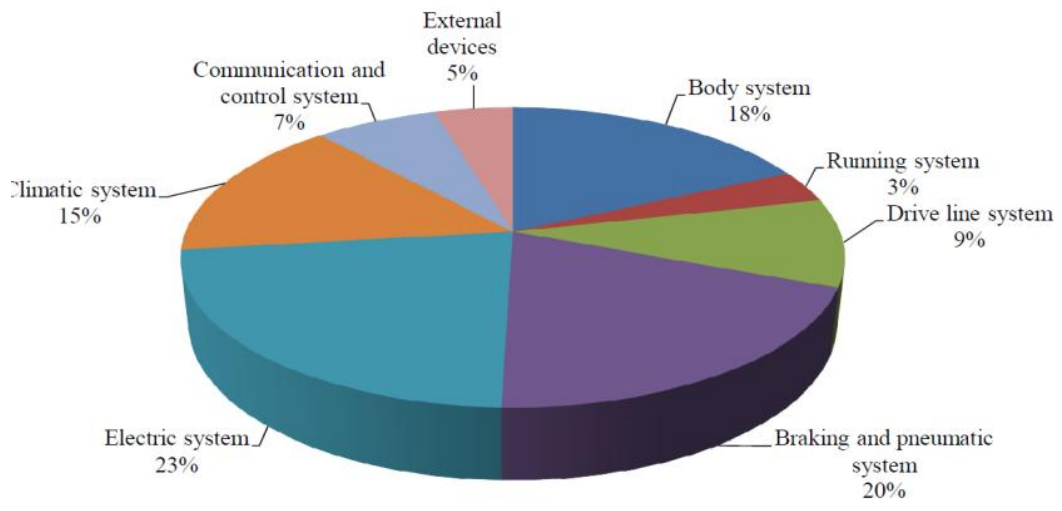

Fig. 8. The percentage of the number of railbuses systems failures

While assigning failures to four groups of failures i.e. critical, important, unimportant and irrelevant, the views of experts are taken into account. The percentage of the number of failures in each group with respect to the total number of failures is shown in Figure 9, whereas the Figure 10 illustrates the percentage of the number of failures, which were noticed in individual functional systems of railbuses with division into the above mentioned four groups of failures.

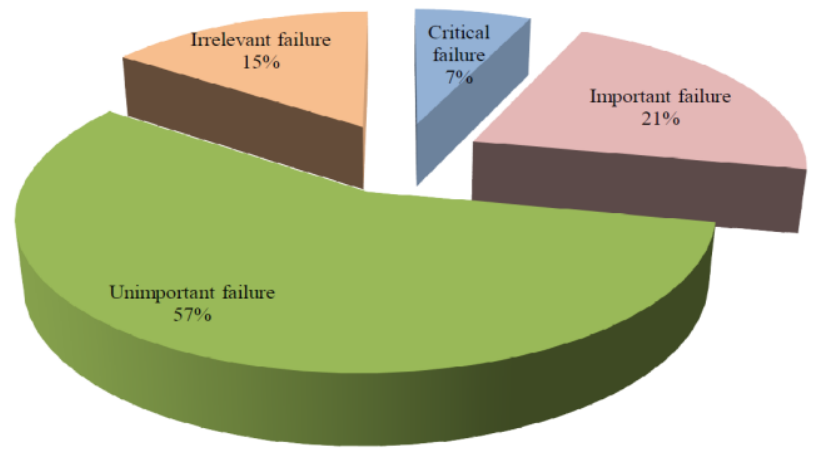

Fig. 9. The percentage of the number of failures in group critical, important, unimportant and irrelevant failures 


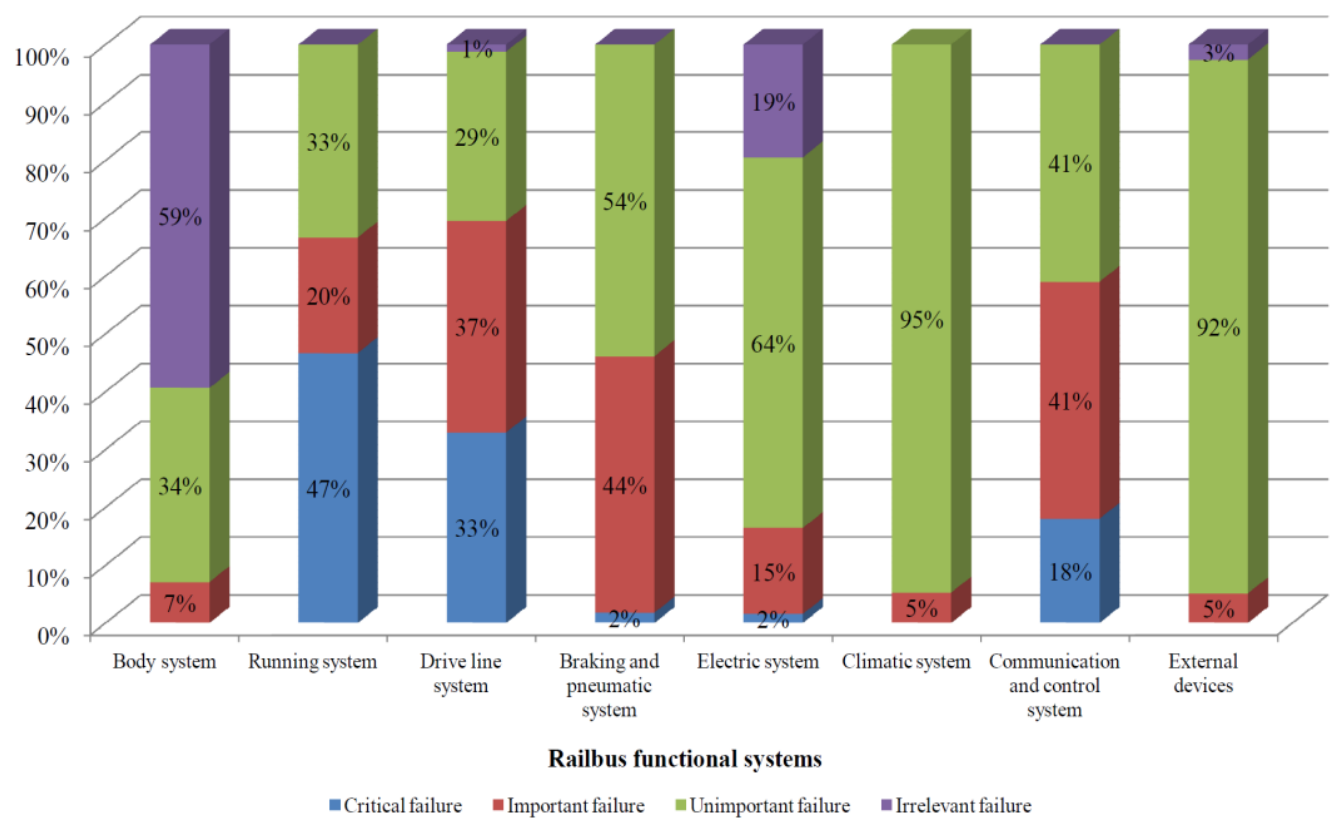

Fig. 10. The percentage of the number of failures, which were noticed in individual the functional systems of railbuses with division into four groups of failures: critical, important, unimportant and irrelevant

As it can be seen at the Figure 9, most failures were observed in the electrical system (23\%) and the braking and pneumatic system (20\%). In both of these systems, the unimportant failures were dominant, respectively $64 \%$ and $54 \%$.

Unlike the failures occurring in the electrical system, a relatively large part of the failures of braking and pneumatic system, required immediate action to restore the object (44\%). It should be also pointed out that a lot of failures of running system, drive line system and communication and control system resulted in the stop of vehicle from further usage or required immediate action to restore their availability. The dominant share of the failures of braking and pneumatic system, running system, drive line system and communication and control system in these two groups, indicates major difficulties in performing transport tasks by the vehicles. Odometer reading from the vehicles at instant of the their failures allowed to calculate times between failures. Next, the sample of the random variable was matched to theoretical distributions. The goodness of fit of the empirical distribution with theoretical distributions by using correlation coefficient $\rho$, is tested. The correlation coefficient $(\rho=0.99)$ verified, on confidence level of $95 \%$, goodness of fit of the empirical distribution of the time between failures of railbuses with lognormal distribution with parameters $\mu=7.8517$ and $\sigma=0.9674$ (Figure 11). This means that the railbuses time between failures can be modeled by distribution lognormal for which the hazard function is a decreasing function. The 
The dependability evaluation of railbuses

Ocena niezawodności autobusów szynowych

decreasing hazard function indicates slow adjustment of railbuses to the operation and maintenance system and improvement of their availability in subsequent periods. The object is improved by removing errors and failures caused by the process of their design and manufacture.



Fig. 11. The cumulative distribution function of railbuses times between failures [kilometers]

The mean time between failures is equal $4104 \mathrm{~km}$ with standard deviation equals to 5108 kilometers. The calculated coefficient of variation is greater than a value 1 (reaches a level about 1.25) - it means that the changeability of observed times between failures is significant. This situation can be connected with the time of operation of railbuses. Information about the time between failures, which have been used in the investigations, came from the initial exploitation period of the railbuses. In this period, the failures were caused by bad design, defective manufacturing, and material imperfections. These failures are random in nature and concerned various elements of railbuses. Consequently, the time between failures is characterized by high changeability and may be very hard to predict.

The collected data made it possible to define the repair times. The realizations of the random variable were transformed in order to obtain the empirical cumulative distribution function. Then, theoretical distributions were fitted to these empirical data. The goodness of fit of distributions was tested, at significance level $\alpha=0.05$, 
by use of correlation coefficient. According to this coefficient $(\rho=0.74)$, the lognormal distribution with parameters $\mu=0.4953$ and $\sigma=0.9204$ produced the best fit of the empirical data (Figure 12). The repair times described by lognormal distribution indicate a tendency to shorten the raibuses repair times, and suggest that the repairs involve the same railbuses components.

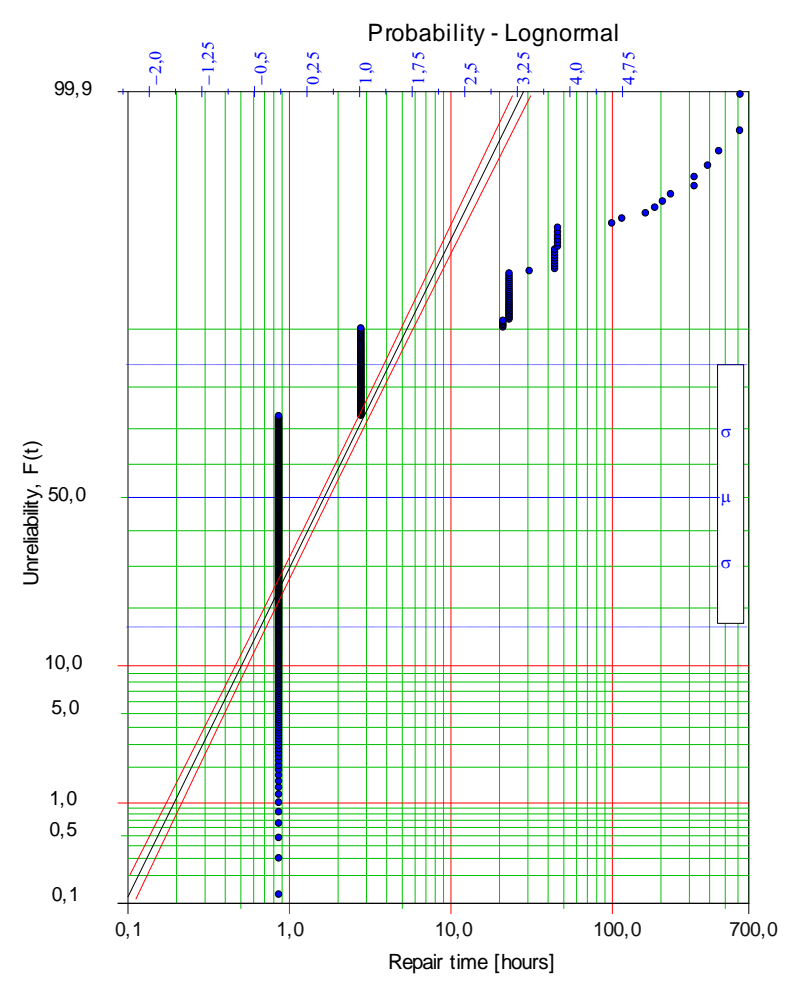

Fig. 12. The cumulative distribution function of railbuses repair times [hours]

The mean repair time equals 2.5 hours with standard deviation equal to 2.9 hours. In this situation, the coefficient of variation value is also greater than 1 (reaches a level of about 1.15). This indicates some problems occurring while maintenance actions are performed. First, during the analysis, the majority of railbuses were in their guarantee period. In this period, more repairs are performed by service of external companies (particularly service of railbuses manufacturer) than service of analysed carrier. The unavailability time of railbuses is longer, when the repairs are carried out by external service. It is related to the arrival of service external companies to the maintenance base of the carrier or the delivery of vehicle, by the carrier, to the maintenance base of external companies. The second problem regards the lack of clear information about the time of maintenance action beginning/finishing of railbuses. 
The dependability evaluation of railbuses

Ocena niezawodności autobusów szynowych

\section{Summary and conclusions}

The collected operation and maintenance documentation and information obtained during visits to the company allow to evaluate the dependability of single mode railbuses of type $X$.

The mean time between failure of approximately $4104 \mathrm{~km}$ and a relatively short repair times (about 2.5 hours) cause the railbuses availability to be relatively high about $90 \%$. The value of this rate oscillates at a very high level, given the fact that the current railbuses are in the Early Failure Period, when the failure rate is high and gradually decreases - in order to stabilize during useful life. This high availability can be justified by short times of repairs of railbuses, which result from the rapid ability of the organization, under given conditions, to provide upon demand, the resources required to maintain an entity. The vehicles are also characterized by high variability of the two analyzed variables - the coefficient of variation is over 1 .

The study findings show that the availability railbuses will be improved and the repair times will be shorter in relation to currently registered in subsequent period of their operation.

Additionally, the analysis shows that the supervision over records is necessary. It is proposed to supplement the documentation with field named the time of maintenance action beginning/finishing of railbuses. As a result, the more detailed analysis of railbuses dependability will be performed.

\section{References}

[1] Dokumentacja Systemu Utrzymania. Autobus szynowy typu X.

[2] Gołąbek A. (pr. zbior.): Niezawodność autobusów. Wydawnictwo Politechniki Wrocławskiej, Wrocław 1993.

[3] Legutko S.: Podstawy eksploatacji maszyn. i urzadzeń. Wydawnictwa Szkolne i Pedagogiczne, Warszawa 2004.



Izabela Dziaduch, PhD student of the Department of Mechanical Engineering at the Wroclaw University of Technology. Research subjects: technical objects' dependability, unavailability costs.

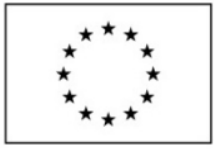

"The research is co-financed by the European Union as part of the European Social Fund" 